\title{
Electron microscopy of desquamative interstitial pneumonia
}

\author{
J. R. SHORTLA N D, C. S. D A R KE, A N D W. A. J . CRANE \\ From the Department of Pathology, University of Sheffield and the Respiratory Function Unit, \\ Royal Infirmary, Sheffield
}

\begin{abstract}
The clinical, radiographical, and physiological picture of two patients suffering from desquamative interstitial pneumonia is described. The diagnosis was established by lung biopsy when the characteristic histological features were found on light microscopy. The dramatic response to adequate corticosteroid therapy is recorded, and attention is directed to the danger of serious relapse on early withdrawal of this treatment and the subsequent satisfactory response to a second course. Electron microscopical studies of the tissue from one patient add materially to the understanding of the clinical course and the nature of the tissue response. At the ultrastructural level the attenuated membranous (type 1) pneumonocytes which normally line the alveoli were replaced by granular (type 2) pneumonocytes. The desquamated intra-alveolar cells comprised two main groups. These were granular pneumonocytes, similar to those lining the alveoli, and smaller numbers of macrophages. The cytopathic effects of virus infection were not detected by light or electron microscopy.
\end{abstract}

In a wide range of diffuse lung disease, biopsy of a representative area remains the only sure way of establishing the definitive diagnosis. The need for accuracy has become more important over the last 10 years since a proportion of these pulmonary disorders will respond to specific therapy, in particular to the use of corticosteroids.

Fibrosing alveolitis, a term proposed by Scadding (1964) to supplant the somewhat inappropriate title of Hamman-Rich syndrome or chronic diffuse interstitial pulmonary fibrosis, is in itself descriptive and sufficiently wide to include a variety of conditions in which the later phases of the illness are seen as a thickening of the alveolar walls and the interstitial framework of the lung. The disorganization, diffuse but uneven in degree, affects the blood-gas exchange area of the lung, and in the past many of these conditions have been reported as cases of 'alveolar-capillary block'. Whereas Hamman and Rich's $(1935$; 1944) original description covered three patients who died after a very short illness (16 weeks at the most) the majority of those categorized as examples of this condition are relatively subacute or chronic, and many patients survive for months or years despite a slow but inexorable downward course.

Within this wide spectrum there appears to exist a specific condition with a relatively benign course, often showing a dramatic response to cortico- steroids. Liebow, Steer, and Billingsley (1965 introduced the descriptive title of desquamative interstitial pneumonia, believing it to be a news condition with characteristic and unique histologig cal features.

The purpose of this article is not to enter the argument as to the originality of the condition they described but to record two patients who have been extensively investigated and in one of whone the opportunity for electron microscopy wa̧ㅗ. attained.

\section{CASE REPORTS}

CASE 1 A.S., a fireman born in 1927, was referree to out-patients with a history of breathlessness on exertion for three months. He also complained of $a$ retrosternal burning sensation, usually in cold weathero after walking fast on the level or up an incline. Thi was not considered to be angina pectoris. On some occasions his wife noticed that his face became purple towards the end of physical effort.

His previous health had been good apart from on occasion in 1954 when he was exposed to high oxygen pressure owing to a faulty reducing valve in the course of a fire fighting practice. He was pulled out of the्ष् smoke chamber but for some weeks felt sore in the throat and chest. Physical examination and a ches radiograph were normal. He returned to work after month. 
In 1963 he presented a rather florid appearance with early finger clubbing and fine crepitations over the lung bases. The chest radiograph showed mottling and linear shadows confined to the lower lobes. There was no pleural involvement. The cardiac silhouette was normal (Fig. 1a). The electrocardiogram and blood count were normal. The E.S.R. was $17 \mathrm{~mm}$. in one hour.

A diagnosis of pulmonary sarcoidosis was considered but seemed unlikely as the tuberculin test was strongly positive. Fibrosing alveolitis was thought to be possible but as he was able to work no further investigation was then arranged. During the next 10 months breathlessness progressed with mild loss of weight but there was never any cough, sputum or wheezing. Eventually he had to give up work and was admitted to hospital in November 1963 for further study.

No new physical signs were noted and the chest radiograph was unchanged. Severe distress with obvious central cyanosis was confirmed on exercise and supported by arterial blood samples, yielding a normal resting $p \mathrm{H}$ and $\mathrm{PCO}_{2}$ but an oxygen saturation of $87.5 \%$, falling to $62 \%$ immediately after exertion. Respiratory function tests revealed no airways obstruction but a much reduced vital capacity of $2,125 \mathrm{ml}$. estimated at $43 \cdot 5 \%$ of predicted value. The diffusion capacity was normal at rest (Table I). Since no definitive diagnosis had been established, a biopsy of a representative portion of the left lower lobe was obtained at open thoracotomy on 21 January 1964.

After a short interval prednisolone was started, initially at $45 \mathrm{mg}$. daily, reducing to $20 \mathrm{mg}$. daily. The patient returned to work after six weeks' convalescence and has kept moderately well since, on a maintenance dose of prednisolone which has varied between 5 and $10 \mathrm{mg}$. daily. Serial radiographs over the past four years have shown progressive shrinkage of the lower lobes (Fig. 1b).

CASE 2 C.S., an apprentice hairdresser born in 1947, was admitted to the White House Hospital, Boston, in August 1965 with a complaint that she had been breathless on climbing stairs for the past four months. The onset had been insidious with no obvious predisposing cause and unaccompanied, initially, by other respiratory symptoms. Eventually she had to give up work because of general malaise, increasing distress, and an unproductive cough. Physical examination revealed only crepitations at the base of the right lung and gross finger clubbing.

Chest radiography revealed pin-head nodulation, unevenly distributed throughout both lungs. The greater part of the right lung and the left lower lobe appeared to be affected (Figs $2 a$ and $b$ ).

In view of the mild fever she was treated with intramuscular penicillin, tetracycline with nystatin, and later ampicillin. Her general condition improved and the temperature fell to normal, but there was no clearing of the radiographic shadows. She was discharged after two months' observation but soon relapsed with an increase of breathlessness, further weight loss, and a persistent dry cough. In November 1965 and again in February 1966 she received prednisolone in low dosage over a period of a few weeks with perhaps temporary improvement but the general course was downhill. In view of the gravity of the illness and its obscure nature she was referred to Sheffield in April 1966 for consideration of a lung biopsy.

She had worked with four other girls in a hairdressing salon for 26 months. The room was small and stuffy and had no artificial ventilation. She would

T A B L E I

RESPIRATORY FUNCTION

\begin{tabular}{|c|c|c|c|c|c|c|c|c|c|}
\hline & Predicted & 21.11 .62 & 7.11 .63 & 9.1 .64 & 21.2 .64 & 27.11 .64 & 20.2 .66 & 21.7 .67 & 14.8 .68 \\
\hline 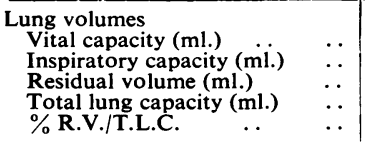 & $\begin{array}{l}4,850 \\
3,650 \\
2,100 \\
6,950 \\
29\end{array}$ & $\begin{array}{l}- \\
- \\
-\end{array}$ & $\begin{array}{l}- \\
-\end{array}$ & $\begin{array}{l}E \\
\overline{-}\end{array}$ & $\begin{array}{l}2,825 \\
1,925 \\
1,250 \\
4,075 \\
30 \cdot 8\end{array}$ & $\begin{array}{l}\overline{-} \\
\bar{z}\end{array}$ & $\begin{array}{l}\text { - } \\
\text { - }\end{array}$ & $\begin{array}{l}E \\
z\end{array}$ & $\begin{array}{c}2,538 \\
1,950 \\
992 \\
3,730 \\
26 \cdot 6\end{array}$ \\
\hline 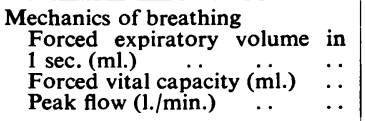 & $\begin{array}{r}3,850 \\
4,950 \\
510\end{array}$ & $\begin{array}{r}3,250 \\
4,000 \\
517\end{array}$ & $\begin{array}{r}2,050 \\
2,125 \\
402\end{array}$ & $\begin{array}{r}1,625 \\
1,675 \\
340\end{array}$ & $\begin{array}{r}2,350 \\
2,633 \\
552\end{array}$ & $\begin{array}{r}2,098 \\
2,592 \\
565\end{array}$ & $\begin{array}{r}2,043 \\
2,475 \\
473\end{array}$ & $\begin{array}{r}2,150 \\
2,667 \\
523\end{array}$ & $\begin{array}{r}2,015 \\
2,283 \\
480\end{array}$ \\
\hline 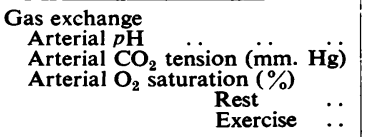 & $\begin{array}{l}7 \cdot 4 \\
40 \\
95 \\
95\end{array}$ & $\begin{array}{l}- \\
-\end{array}$ & $\begin{array}{r}7 \cdot 42 \\
40 \cdot 65 \\
87 \cdot 5 \\
62 \cdot 0\end{array}$ & $\begin{array}{l}- \\
-\end{array}$ & $\begin{array}{l}- \\
-\end{array}$ & $\begin{array}{l}- \\
z\end{array}$ & $\begin{array}{l}- \\
-\end{array}$ & $\begin{array}{l}- \\
z\end{array}$ & $\begin{array}{l}7 \cdot 37 \\
44 \cdot 0 \\
88 \cdot 5 \\
-\end{array}$ \\
\hline 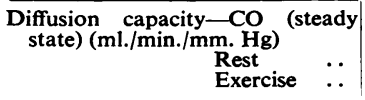 & $\underline{20 \cdot 5}$ & E & $\underline{18}^{-0}$ & $\underline{10}^{10 \cdot 8}$ & $\underline{19}^{-8}$ & $\begin{array}{l}24 \cdot 0 \\
40 \cdot 5\end{array}$ & $\begin{array}{l}20 \cdot 1 \\
35 \cdot 4\end{array}$ & - & $\underline{12}^{-9}$ \\
\hline
\end{tabular}

Case 1, male, aged 39, ht. $178 \mathrm{~cm}$., wt. $77 \mathrm{~kg}$. Lung biopsy 21.1.64. Corticosteroid therapy begun 28.1.64. 


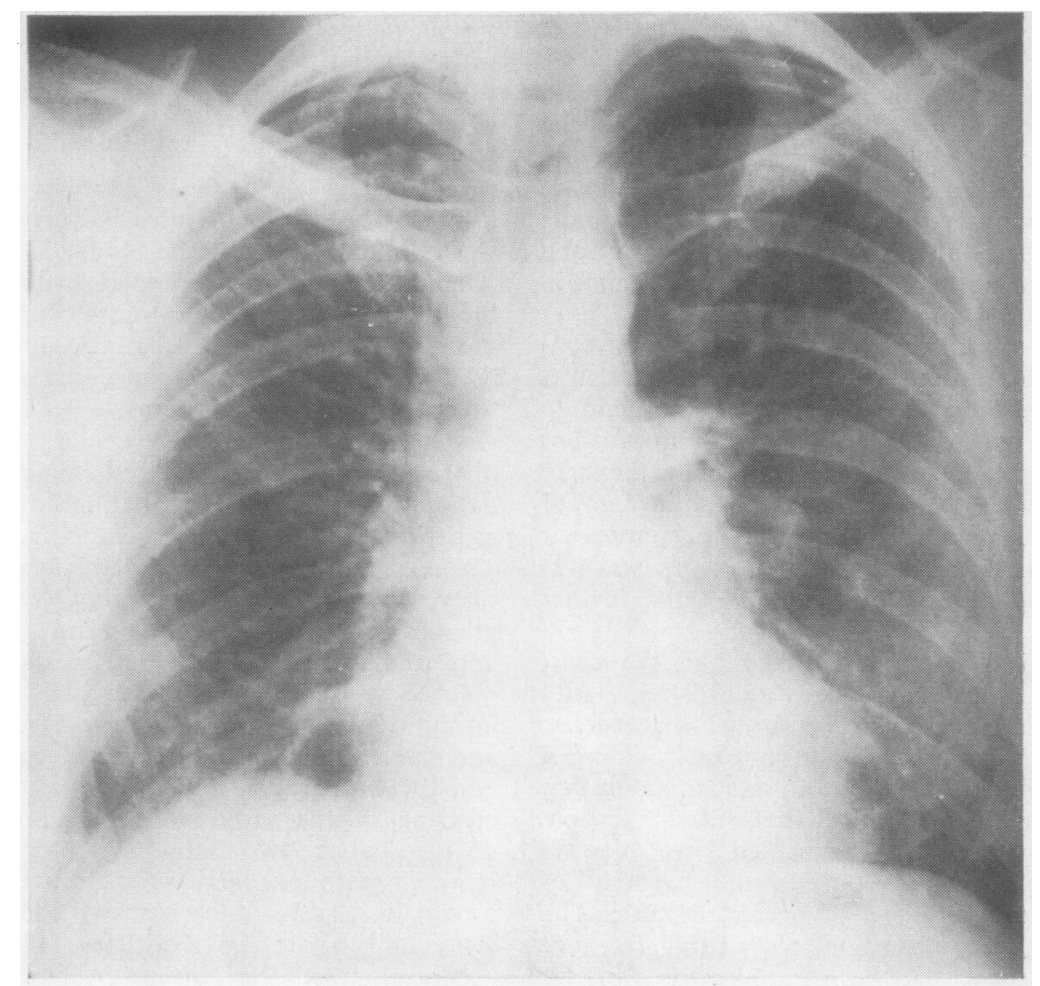

(a)

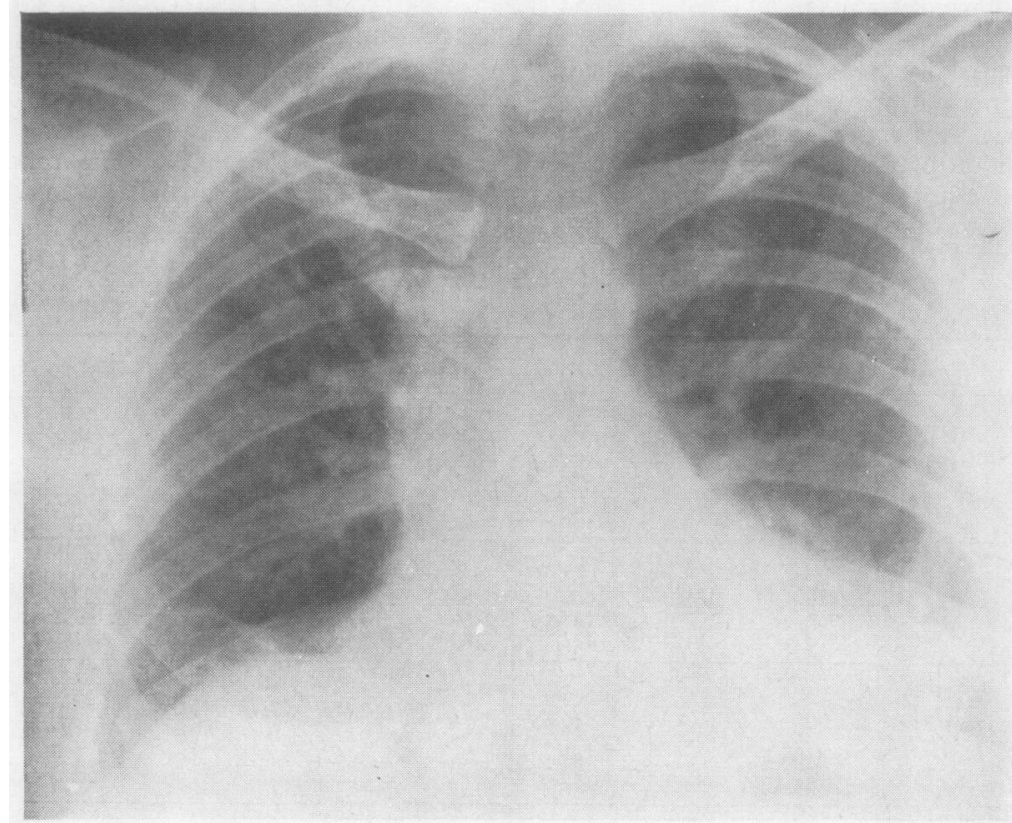

(b)

FIG. 1. Case 1. Male aged 35 years: radiographs of chest (a) in 1962 showing mottled shadows confined to lower zones of both lungs; (b) in 1968 showing persistence of basal opacities above a raised diaphragm. 


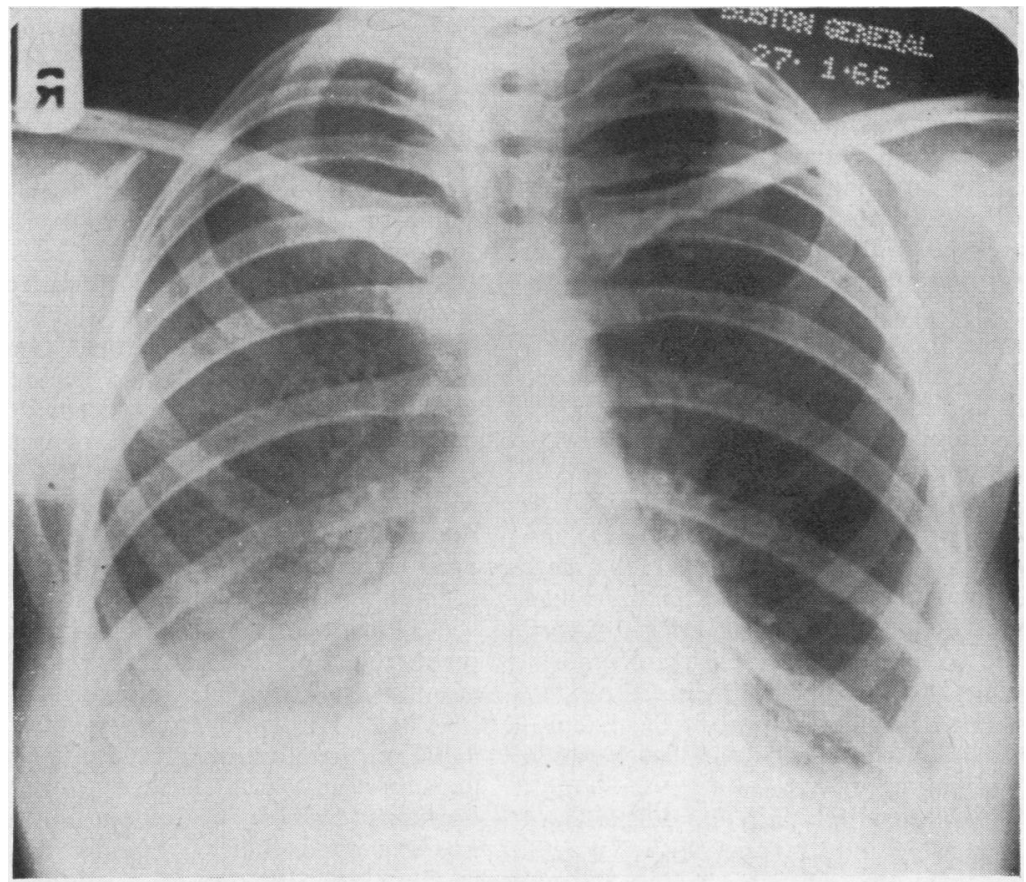

(a)

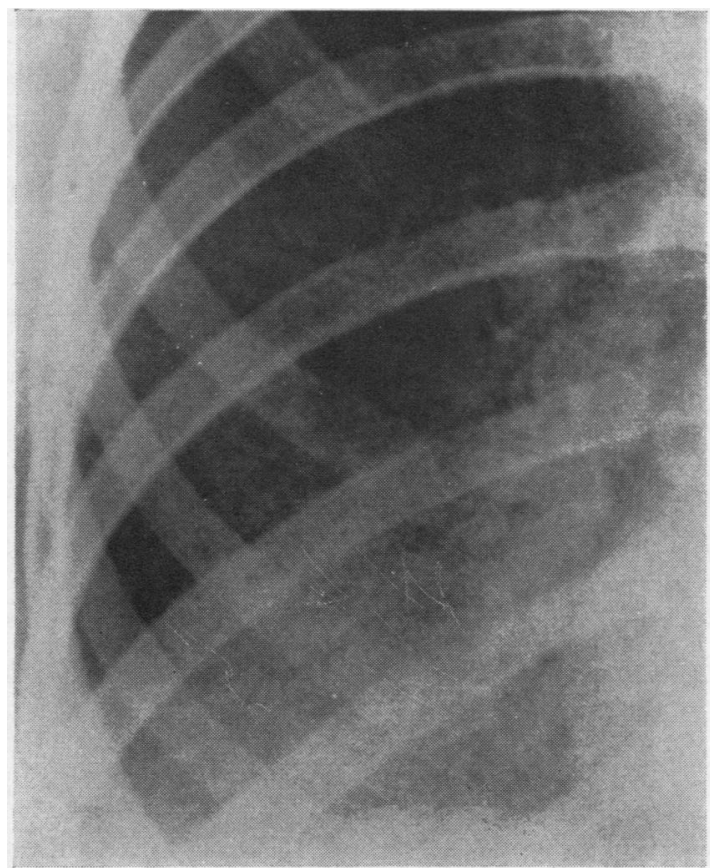

FIG. 2. Case 2. Female aged 19 years: (a) radiograph of chest showing pin-head nodulation of the greater part of the right lung and linear shadows at the left base; $(b)$ enlargement of right middle and lower zones showing the nodulation more clearly. 
personally have dealt with about 100 customers per week and half of these at weekends. Various proprietary hair sprays were employed by all the assistants, of which the base was probably shellac. Her personal use, which was moderate and never more than twice daily, ceased in August 1965 although this was not followed by any improvement in her symptoms. She had not noticed any adverse effect of working with hair sprays. She had suffered from glandular fever at school but had otherwise enjoyed good health. Successful B.C.G. inoculation had been performed at the age of 13 years. She had never smoked. The only allergic reaction recorded was a mild urticaria affecting the face and lips in December 1965.

Clinical examination in April 1966 showed a welldeveloped young woman who had lost $1.5 \mathrm{st} .(9.5 \mathrm{~kg}$.) in weight since the beginning of her illness. Gross finger clubbing, hyperventilation on exercise, and persistent crepitations over the right lower lobe were the only clinical signs. Numerous investigations had been made during the period August 1965 to April 1966, but these had done little to establish a diagnosis. The relevant findings included the following:

Tuberculin test (Heaf) moderately positive ; haemoglobin $16.5 \mathrm{~g} . / 100 \mathrm{ml}$.; white cells totalled between 6,000 and $11,000 /$ cu.mm.; normal differential count and in particular no eosinophilia. The E.S.R. had varied between 15 and $35 \mathrm{~mm}$. in one hour. No L.E. cells were seen. Serum proteins totalled $8.2 \mathrm{~g} . / 100 \mathrm{ml}$., albumin $5 \cdot 2$ g., and globulin $3 \mathrm{~g}$. Urine contained a trace of albumin. Blood urea and electrolytes were normal. Sputum cultures yielded no unusual organism. Respiratory function tests showed a significant reduction in the vital capacity to $41.5 \%$ of predicted value. There was no evidence of airways obstruction or disturbance of distribution of mixing but a severe reduction in gas transfer at rest and on exercise (as measured by the steady state $\mathrm{CO}$ method.) Arterial blood samples taken at rest showed a reduction $i \overline{\bar{m}}$ oxygen tension and saturation with a further fatt immediately following exercise (Table II).

Before proceeding to lung biopsy a routine bronchoक scopy was carried out under general anaesthesia an a small biopsy obtained from the right middle lobe orifice was normal. Bronchial lavage with normat saline of the right lower lobe was also performed in the hope of yielding abnormal cells or other material. Cytological examination revealed only fusiform eosinophilic cells, some of which were ciliated. This examination left the patient very cyanosed and distressed for 24 hours and she required oxygen. I view of this feature it was deemed unwise to proceed to lung biopsy. She was discharged to her home few days later in the belief that she would die an with the advice that she should be treated with large doses of prednisolone in the faint hope that she might again respond. The initial dose was $40 \mathrm{mg}$. daily, later maintained at $30 \mathrm{mg}$. daily.

Within a short period, a dramatic clinical improve ment took place and this was followed over five months by complete clearing of all radiographi opacities. Her vital capacity more than doubled tif $3,400 \mathrm{ml}$. In November 1966, after six months on corticosteroids, it was decided to reduce and stop th: hormone because of certain undesirable side-effect and the good clinical response. Unfortunately withi a few weeks there was a clinical and radiographin relapse with a return to a level of disability almost as bad as before corticosteroids were started. In the circumstances a lung biopsy seemed essential and shē was re-admitted to hospital in April 1967 for biops of the right lower lobe at open thoracotomy.

The post-operative course was uneventful and within. a few days prednisolone, $40 \mathrm{mg}$. in divided doses, was started again. As before, symptomatic relief was dramatic and rapid, although accompanied by conp

T A B L E I I

RESPIRATORY FUNCTION

\begin{tabular}{|c|c|c|c|c|c|c|c|c|}
\hline & & & Predicted & 19.4.66 & 26.9 .66 & 3.4 .67 & 11.9 .67 & 5.8 .68 \\
\hline $\begin{array}{l}\text { Lung volumes } \\
\text { Vital capacity (ml.) } \\
\text { Inspiratory capacity (ml.) } \\
\text { Residual volume (ml.) } \\
\text { Total lung capacity (ml.) } \\
\% \text { R.V./T.L.C. .. }\end{array}$ & $\begin{array}{l}\cdots \\
\cdots \\
\cdots \\
\cdots\end{array}$ & $\begin{array}{l}\cdots \\
\cdots \\
\cdots \\
\cdots\end{array}$ & $\begin{array}{r}3,500 \\
2,300 \\
1,500 \\
5,300 \\
27\end{array}$ & $\begin{array}{r}1,450 \\
725 \\
930 \\
2,355 \\
39 \cdot 5\end{array}$ & $\begin{array}{l}3,400 \\
2,750 \\
1,030 \\
4,430 \\
23 \cdot 4\end{array}$ & $\begin{array}{r}2,837 \\
2,000 \\
750 \\
3,670 \\
20 \cdot 7\end{array}$ & $\begin{array}{l}- \\
- \\
-\end{array}$ & $\begin{array}{r}3,150 \\
870 \\
4,295 \\
20 \cdot 2\end{array}$ \\
\hline $\begin{array}{l}\text { Mechanics of breathing } \\
\text { Forced expiratory volume in } 1 \text { se } \\
\text { Forced vital capacity (ml.) } \\
\text { Peak flow (1./min.) }\end{array}$ & $\begin{array}{c} \\
\text { ec. }(\mathrm{ml} .) \\
\quad \cdots \\
\cdots\end{array}$ & $\begin{array}{l}\cdots \\
\cdots \\
\cdots\end{array}$ & $\begin{array}{r}3,000 \\
3,450 \\
87\end{array}$ & $\begin{array}{l}1,175 \\
1,385 \\
30 \cdot 8\end{array}$ & $\begin{array}{r}2,735 \\
3,363 \\
455\end{array}$ & $\begin{array}{r}2,475 \\
2,983 \\
437\end{array}$ & $\begin{array}{r}2,850 \\
3,500 \\
390\end{array}$ & $\begin{array}{r}2,735 \\
3,367 \\
370\end{array}$ \\
\hline $\begin{array}{l}\text { Gas exchange } \\
\text { Arterial } p \mathrm{H} \\
\text { Arterial } \mathrm{CO}_{2} \text { tension }(\mathrm{mm} . \mathrm{Hg}) \\
\text { Arterial } \mathrm{O}_{2} \text { saturation }(\%)\end{array}$ & $\begin{array}{l}\quad \cdots \\
\text { Rest } \\
\text { Exercise }\end{array}$ & $\begin{array}{l}\cdots \\
\cdots \\
\cdots\end{array}$ & $\begin{array}{l}7 \cdot 4 \\
40 \\
95 \\
95\end{array}$ & $\begin{array}{l}7 \cdot 37 \\
39 \cdot 5 \\
77 \cdot 5 \\
62\end{array}$ & 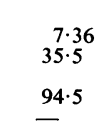 & $\begin{array}{l}- \\
- \\
-\end{array}$ & $\begin{array}{l}- \\
-\end{array}$ & 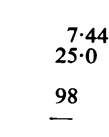 \\
\hline $\begin{array}{l}\text { Diffusion capacity - CO (steady st } \\
\mathrm{mm} . \mathrm{Hg})\end{array}$ & $\begin{array}{l}\text { ate) }(\mathrm{ml} . / \mathrm{r} \\
\text { Rest } \\
\text { Exercise }\end{array}$ & $\begin{array}{l}\text { in.l } \\
\cdots \\
\cdots\end{array}$ & $\underline{20 \cdot 5}$ & $\begin{array}{r}6.05 \\
12.45\end{array}$ & - & $\underline{17}^{17 \cdot 5}$ & - & $\underline{12}^{12 \cdot 0}$ \\
\hline
\end{tabular}




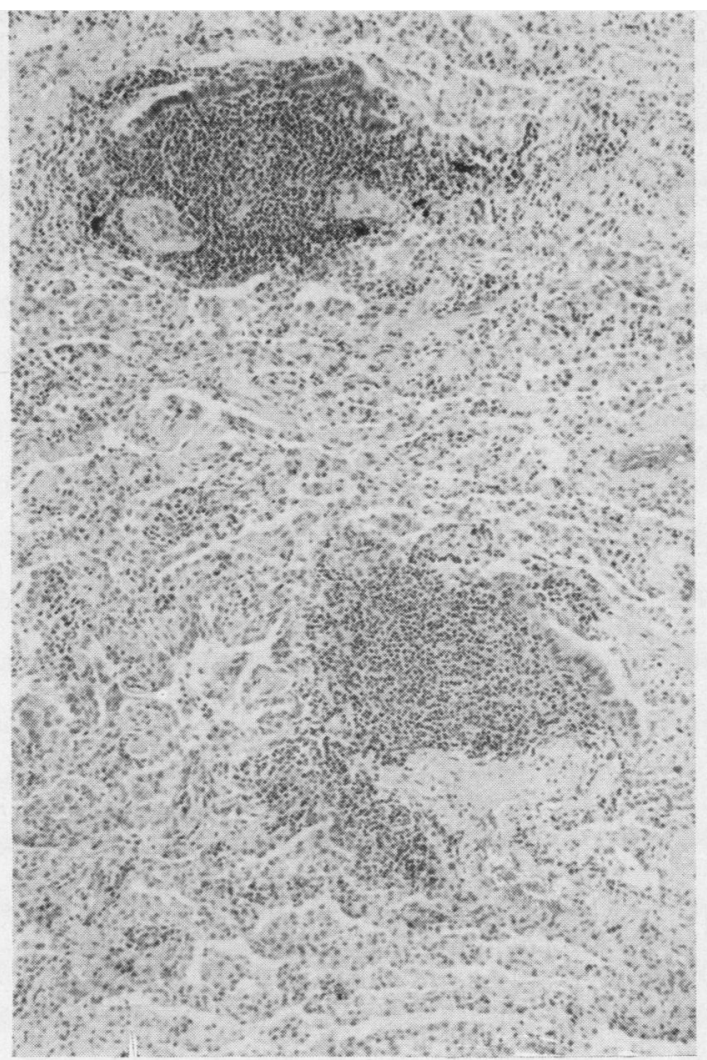

FIG. 3

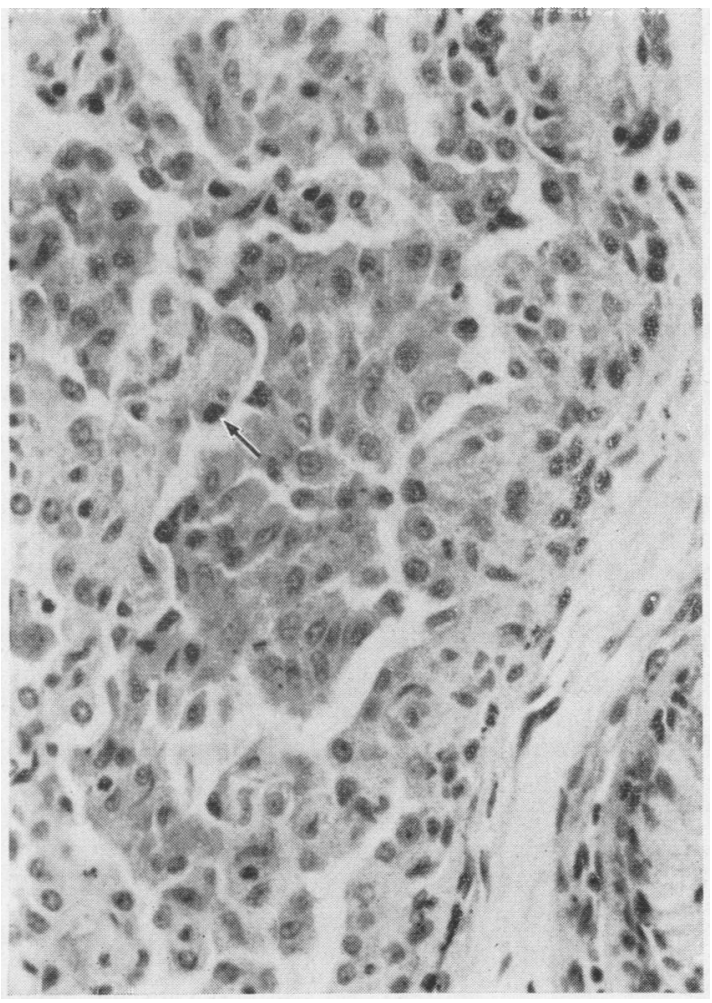

FIG. 4

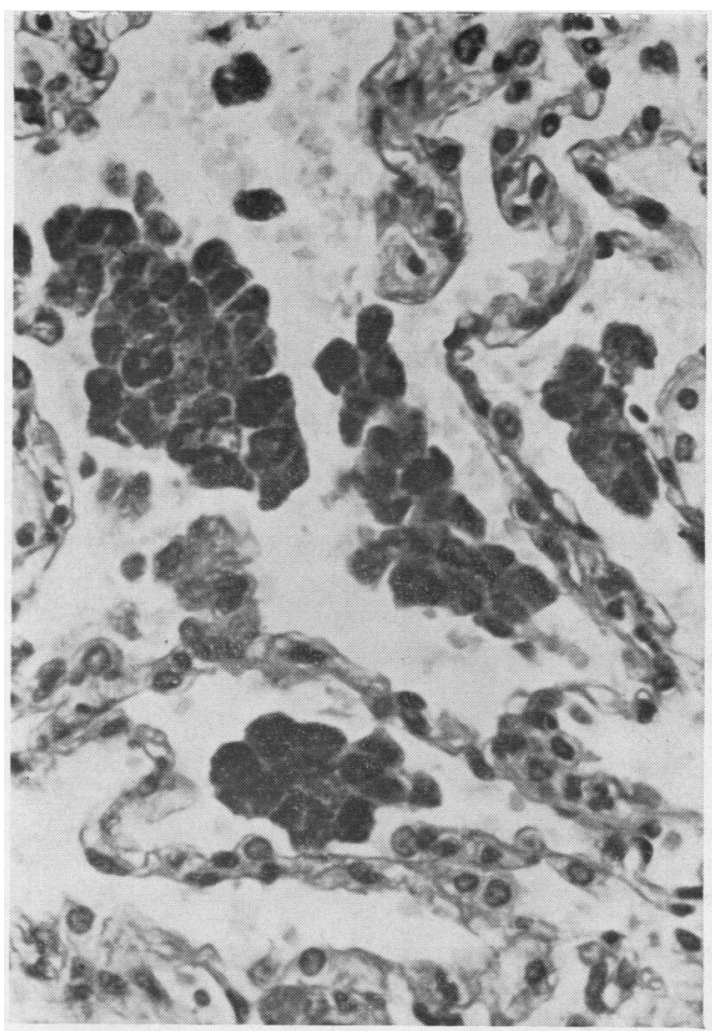

FIG. 5

FIG. 3. Case 1. Uniform filling of distal air spaces by desquamated large alveolar cells, but no disruption of alveolar septa. Two lymph aggregates are related to terminal bronchioles and there is further diffuse cell infiltration with lymphocytes and plasma cells. $H$. and $E$. $\times 45$.

FIG. 4. Case 1. The alveolar space is filled with desquamated cells and similar cells line the alveolar wall. One of the latter (arrow) is in mitosis. A few eosinophils are also present. $H$. and $E . \times 270$.

FIG. 5. Case 2. Desquamated cells giving a strong positive $P$.A.S. reaction in the cytoplasm are present in the alveolar spaces. H. and P.A.S. $\times 420$. 
siderable weight gain. Again there was progressive radiographic clearing of the nodular shadows. In August 1968 she considered herself quite normal (Table II). No added sounds were audible over the lungs and finger clubbing had regressed. After the initial response a small dose of 7.5-10 mg. prednisolone has been sufficient to maintain her in good health.

\section{PATHOLOGICAL FINDINGS}

HISTOLOGY The lung biopsies from both patients were examined with the light microscope using a variety of staining techniques. They showed the range of histological features designated desquamative interstitial pneumonia (D. I. P.) by Liebow et al. (1965).

A principal feature was the desquamation of large alveolar cells into the distal air spaces. This involved around $90 \%$ of the air spaces of case 1 and approximately $40 \%$ in case 2 (Fig. 3). Many alveoli were completely filled with these cells and

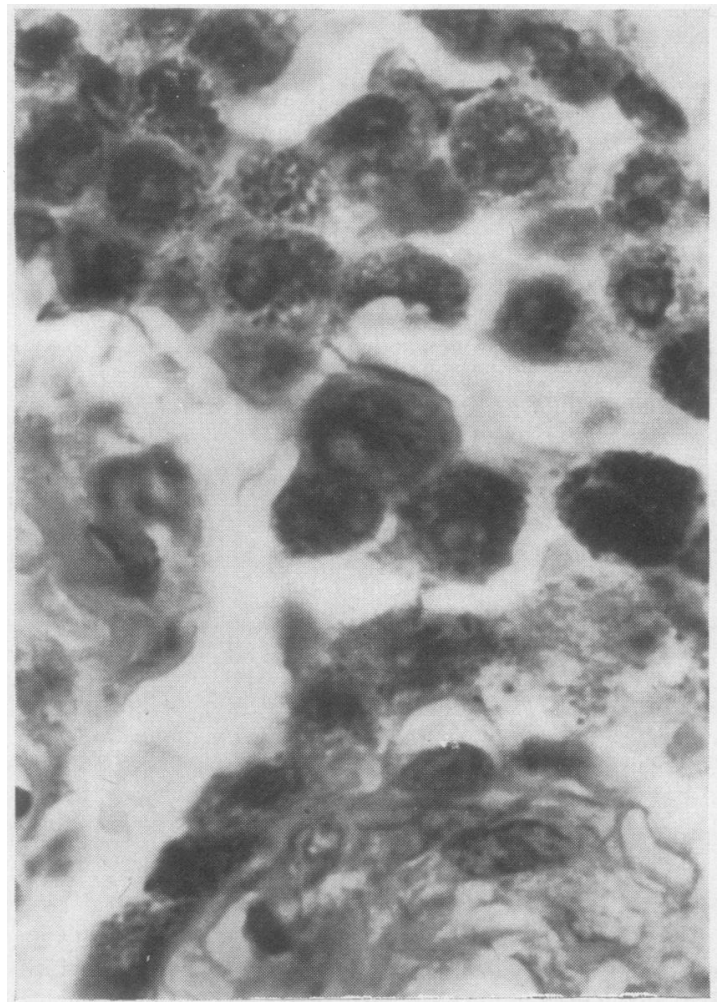

FIG. 6. Case 2. Oil-immersion photograph showing P.A.S.positive granularity of cells lining the alveolar walls and a similar reaction in the cytoplasm of the desquamated cells. H. and P.A.S. $\times 1,015$. some, showing mitotic activity, lined a proportiono of the alveolar walls (Fig. 4). Characteristically듬 they showed a deeply eosinophilic cytoplasm which gave a pronounced positive granularity with P.A.S. $\widetilde{D}$ and resisted diastase digestion (Figs 5 and 6). Perl's stain for iron was positive in a minority of ${ }^{\text {s }}$ cells and here the reaction was diffuse. A few cells. showed positive staining with Mallory's stain for $\overrightarrow{\vec{H}}$ lipofuscin. Carbon pigment in the desquamated ${ }^{\omega}$ cells was virtually non-existent although present within the interstitial framework of the lung. $\mathrm{An}_{\mathrm{N}}^{\times}$ occasional giant cell with a single enlarged nucleus and similar cytoplasmic characteristics was. observed within the air spaces in relation to the more uniform masses of desquamated cells (Fig. 7).0 Birefringent foreign material was not seen. Necrosis was absent.

Lymphoid aggregates were present in both biopsies (Figs 3 and 8 ). They were distributed in? the framework of the alveolar spaces, in the walls of some terminal bronchioles, thereby distortingo them, and beneath the pleura. The pleura itself was a little oedematous but showed no significanos fibrous thickening in either patient. The lymph follicles were most marked in case 1 but in neithe did they show germinal centres. Scattered more⿱ diffusely through the interstitial framework were further lymphocytes along with some plasma $\overrightarrow{\overrightarrow{0}}$ cells and eosinophils (Fig. 3). In case 1 a few eosinophils were present with the desquamated alveolar cells in the air spaces (Fig. 4), and a. scattering of neutrophils was also observed.

Alveolar wall thickening resulted from fibro blast and smooth muscle proliferation and the laying down of collagen fibres and argyrophilic 3 reticulin in the biopsy from case 2 . These featuresin were not prominent in our first patient. Arterias thickening has been described in D.I.P. by Liebow et al. (1965), Gaensler, Goff, and Prowse (1966)? and Persaud, Bateson, Ling, and Hayes (1967) a a result of muscle hypertrophy and mural fibrosis Subendothelial oedema was a feature in smalb lung arteries from both our patients but the estab i lished changes noted above were not encountered N

ELECTRON MICROSCOPY Material for electron microscopy was obtained at open thoracotomyC from the right lower lobe of case 2 . A slice $(1 \mathrm{~mm}$ thick) was rapidly placed in $1 \%$ osmium tetroxide buffered with veronal acetate (Palade, 1952) and then cut into $1-\mathrm{mm}$. squares during a two-hou侣 period of fixation on ice. Dehydration throught graded alcohols was followed by araldite embed $\cong$ ding (Glauert, 1961), and sections were cut witk a Porter Blum Ultratome using glass knives. Thiro 


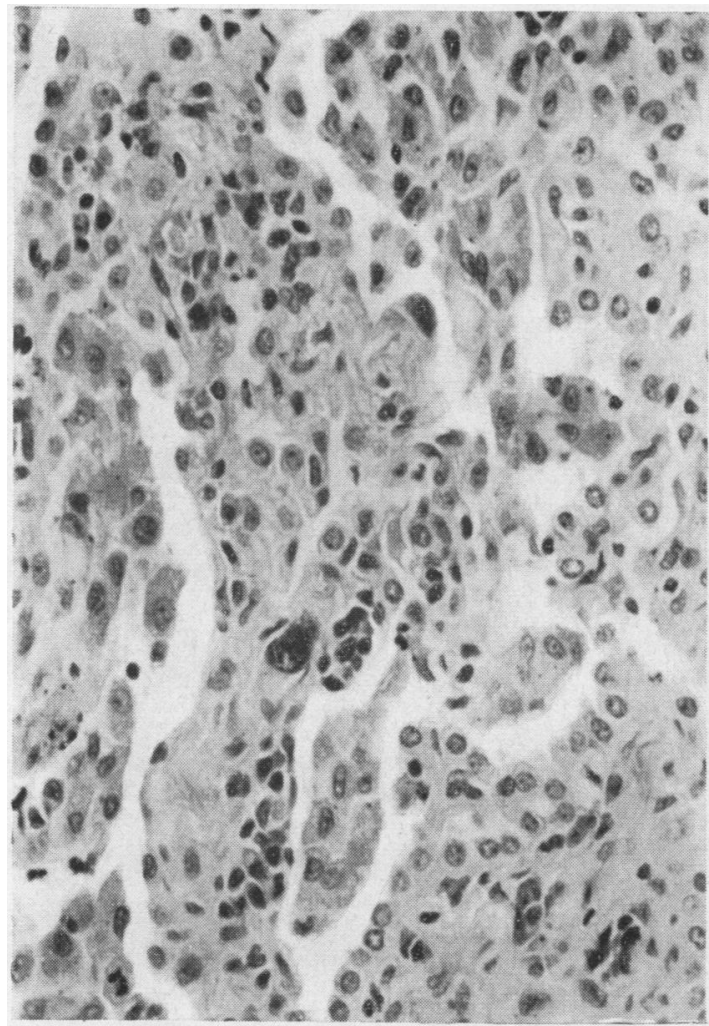

FIG. 7. Case 1. A giant cell is present within the desquamated alveolar cells. There is also a scattering of lymphocytes. $H$. and $E$. $\times 270$.

sections (60-90 $\mathrm{m} \mu$ ) were mounted on uncoated copper grids, stained with lead citrate (Reynolds, 1963), and examined with an A.E.I. E.M. 6 electron microscope at accelerating voltages of 50 and $75 \mathrm{kV}$.

At the ultrastructural level a principal abnormality was the replacement of the attenuated cells (membranous, type 1) that normally line most of the lung alveoli by type 2 or granular pneumonocytes. As well as this alteration in the type of cell bordering the alveolar wall, granular pneumonocytes were also found in the alveolar spaces (Fig. 9). The population of so-called desquamated cells comprised two main groups. These were type 2 pneumonocytes which formed the major intraalveolar cell component along with smaller numbers of alveolar macrophages. The alveolar septa were thickened in case 2 , as noted above, by collagen produced by septal cells.

The type 2 (granular) pneumonocytes lining the alveolar septa and apparently lying free in the air spaces were characterized by multiple laminated

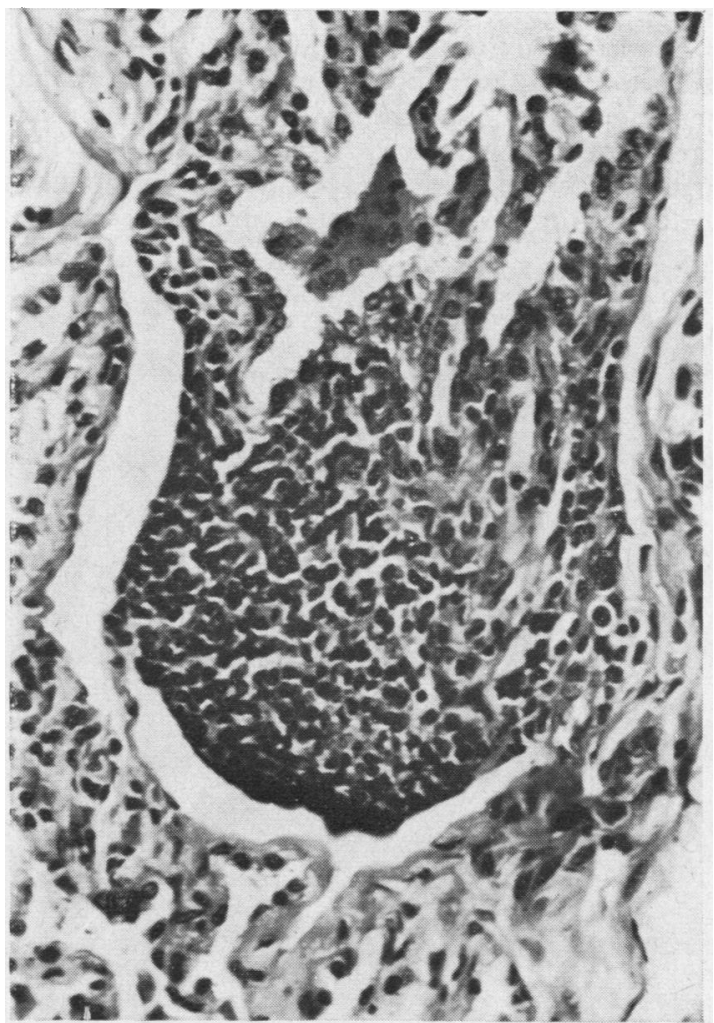

FIG. 8. Case 2. A small lymphoid aggregate is depicted. A group of desquamated alveolar cells is also seen (above). $H$. and $E . \times 255$.

inclusions within their cytoplasm (Figs 9, 10, and 11). The cell outline was irregular due to many short stubby microvilli which often made contact with the alveolar septum (Fig. 9). Where the cell surfaces of adjacent granular pneumonocytes were in apposition, the microvillous arrangement gave way to complex cellular invaginations. Condensations of the plasma membrane, characteristic of terminal bars, occurred at cell junctions (Fig. 11). The nuclei which were round or oval with a regular limiting membrane contained one or sometimes two prominent nucleoli. The rough endoplasmic reticulum presented short profiles, with dilatation of the cisternae forming vacuoles. The Golgi apparatus, prominent in many cells, gave rise to numerous smooth-walled vesicles (Fig. 11), and fine filamentous fibrils were present within some areas of the electron-lucent cytoplasm. Ribosomes, either free or in cochlear form, with occasional glycogen particles and infrequent mitochondria, most of normal configuration, were present within the cytoplasm. 
Laminated lysosomal bodies were a dominant feature within the cytoplasm of the type 2 granular pneumonocyte. These bodies existed in two principal morphological forms (Figs 10 and 11). The first was characterized by electron-dense laminae, the layers of which converged upon an eccentric electron-dense core which attached the layers to an outer limiting membrane. The laminae wereo separated one from the other by amorphous material of medium density (Fig. 10). The secondo form of laminated body was less compact and itsy layers were separated individually and from the

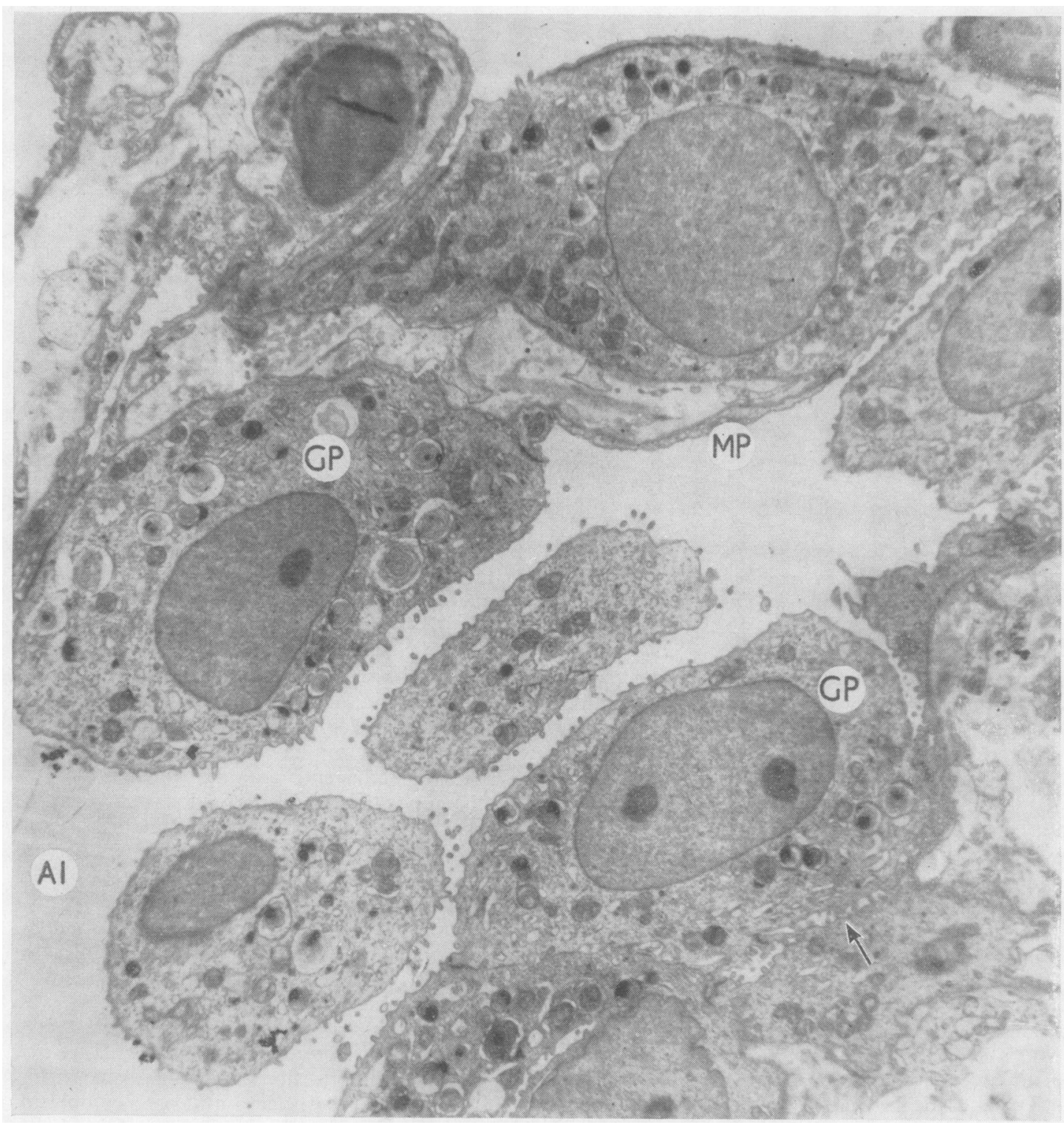

FIG. 9. An alveolar air space (A1) lined chiefly by type 2 (granular) pneumonocytes (GP), with an occasional type 1 (membranous) pneumonocyte (MP). Some granular pneumonocytes are dislodged, apparently free in the air space. Contact with the alveolar septum by microvillous processes of the granular pneumonocyte is shown (arrow). The junction between type 2 cells shows cellular invaginations. Lead stain $\times 3,450$. 
bounding membrane by low-density amorphous material which at the periphery formed an incomplete halo (Fig. 11).

An occasional type 2 cell, apparently degenerating, showed cribriform cisternal dilatation of the endoplasmic reticulum, ballooning of the mitochondria, and loss of their granules.

The alveolar macrophages, fewer in numbers than the granular pneumonocytes, were found among the intra-alveolar cells (Fig. 12) and also within the septa (Fig. 15). Morphologically they were distinguished by very dense intracellular lysosomes in which lamination was infrequent and variability in size more pronounced (Fig. 12). Most were bounded by a unit membrane. They contained a heterogeneous collection of materials including lipid (Fig. 13) and dense granules, probably lipofuscin (Fig. 14). These components, along with lipoprotein laminae (Fig. 14), tended to mask small, relatively sparse ferritin granules.

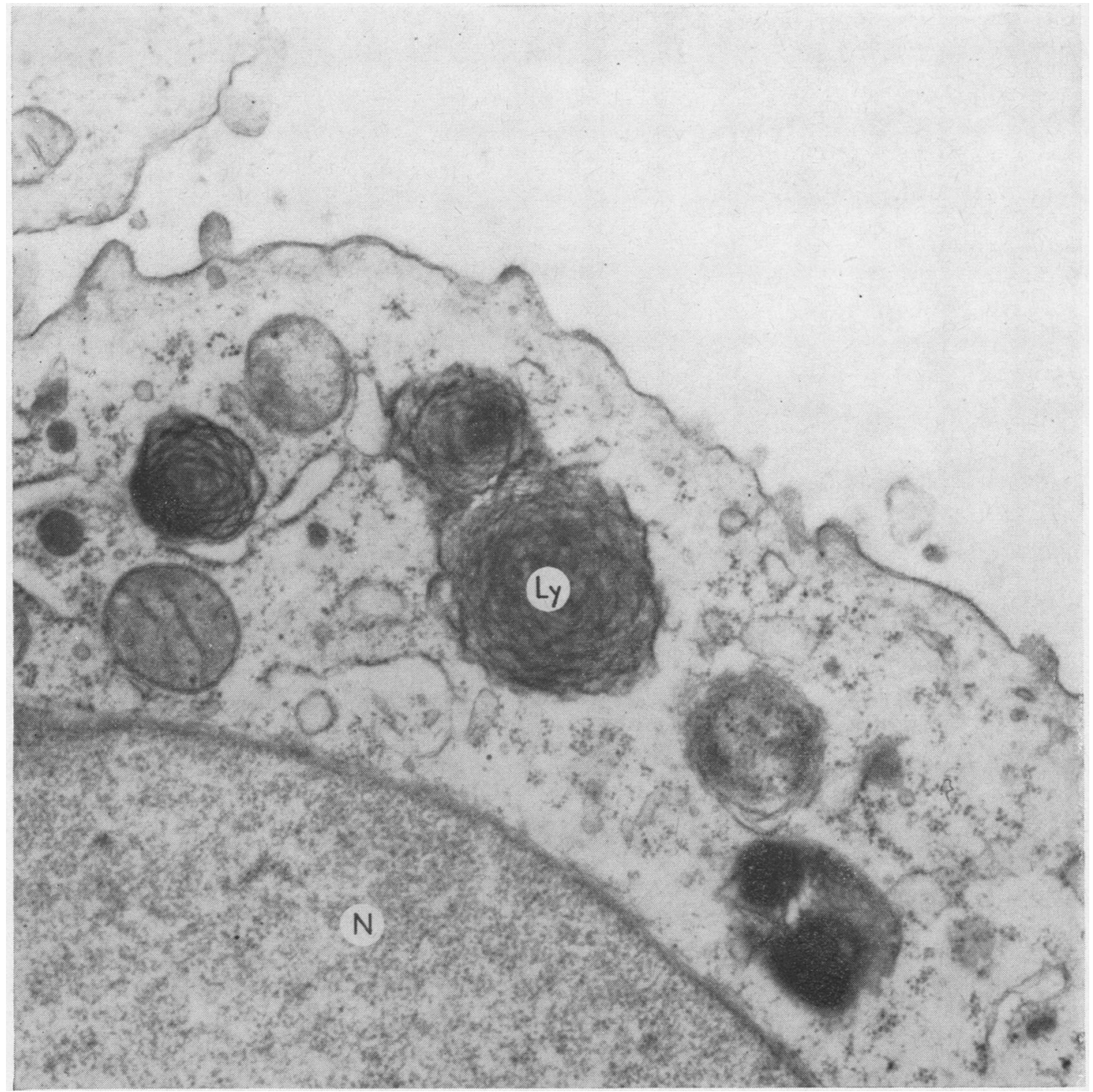

FIG. 10. Type 2 pneumonocyte showing laminated lysosomal bodies (Ly) in the cytoplasm. The nucleus is shown $(N)$. Short microvillous processes are present at the periphery of the cell. Lead stain $\times 33,850$. 
Macrophages also had fewer microvilli than adjacent granular pneumonocytes although an occasional example produced long pseudopodia. The nucleus, which also showed prominent nucleoli, was round or oval but more irregular in outline than those of type 2 cells (Fig. 12). Mitochondria, more frequent than in the granular cells, were found together with elements of rough and smooth endoplasmic reticulum, ribosomes, and glycogen particles. Fine filamentous material and a scattering of ferritin granules were seen in the cytoplasm at high magnification. The Golgi apparatus was also more prominent than in the granular pneumonocytes (Fig. 12).

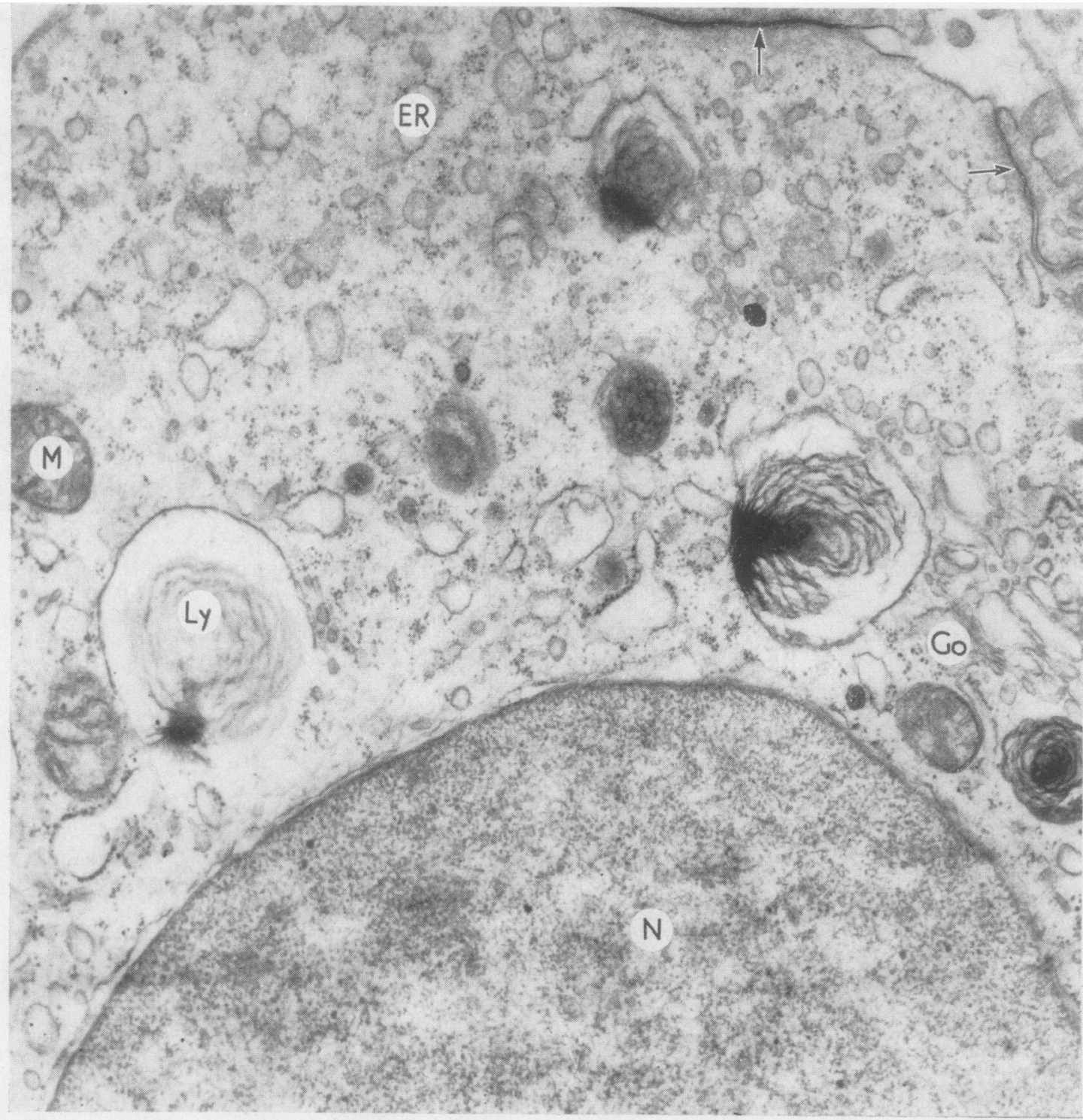

FIG. 11. Granular pneumonocyte showing the characteristic laminated bodies (Ly) surrounded by an incomplete halo. Mitochondria $(M)$ are sparse. Smooth and rough endoplasmic reticulum $(E R)$ show rounded profiles. Smoothwalled vesicles arise from the Golgi apparatus (Go). Terminal bars (arrows) are present. Nucleus $(N)$. Lead stain $\times 27,500$. 
The septa were thickened by collagen produced by septal cells which showed a well-developed endoplasmic reticulum (Fig. 15). Macrophages, identical to those in alveolar spaces, were also identified within the septa along with an occasional polymorph and mast cell.
DISCUSSION

CLINICAL Experience of two patients suffering from D.I.P. hardly justifies a firm opinion of the clinical, radiographical, and physiological picture when set against the larger and wider surveys of

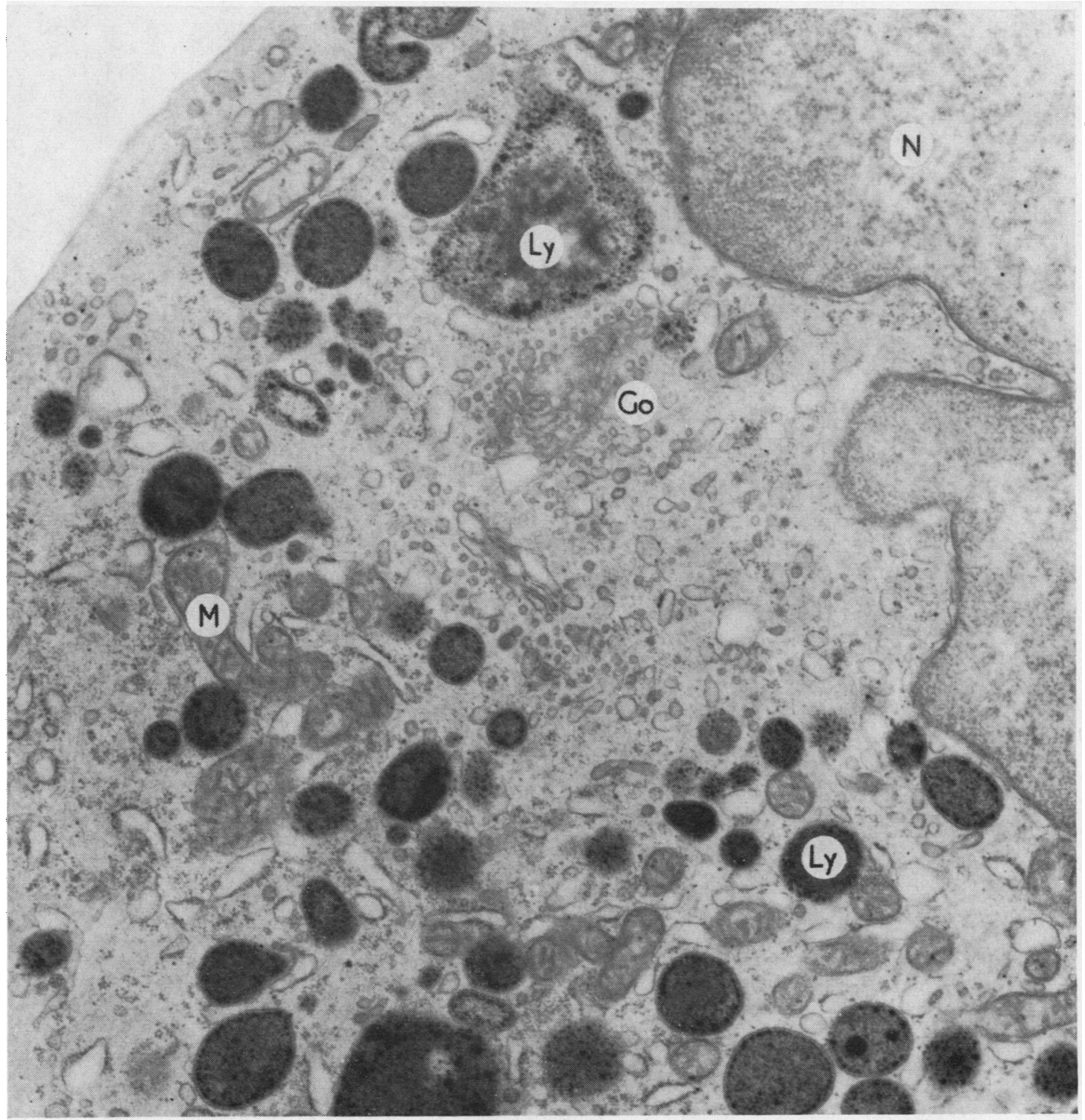

FIG. 12. Intra-alveolar macrophage shows the relationship of the dense lysosomes (Ly) and the prominent Golgi apparatus (Go). The varied appearance of the lysosomes is striking. The nucleus $(N)$ is crenated and mitochondria $(M)$ are more frequent. The cell outline is regular. Lead stain $\times 27,500$. 
Liebow et al. (1965) and Gaensler et al. (1966). There will be general agreement with the pattern outlined by these two writers, but Scadding and Hinson (1967), among other workers, have suggested that it may be unwise to consider D.I.P. as a distinct entity. Without a known aetiological agent it can, from many aspects, conveniently be kept within the group of diffuse interstitial diseases of the lung. Moreover, many of the chronic cases diagnosed following lung biopsy may represent a late phase of D.I.P., through which the patient has passed months or years previously. Serial biopsies have shown progressive changes and, in the advanced stages, differentiation is impossible.

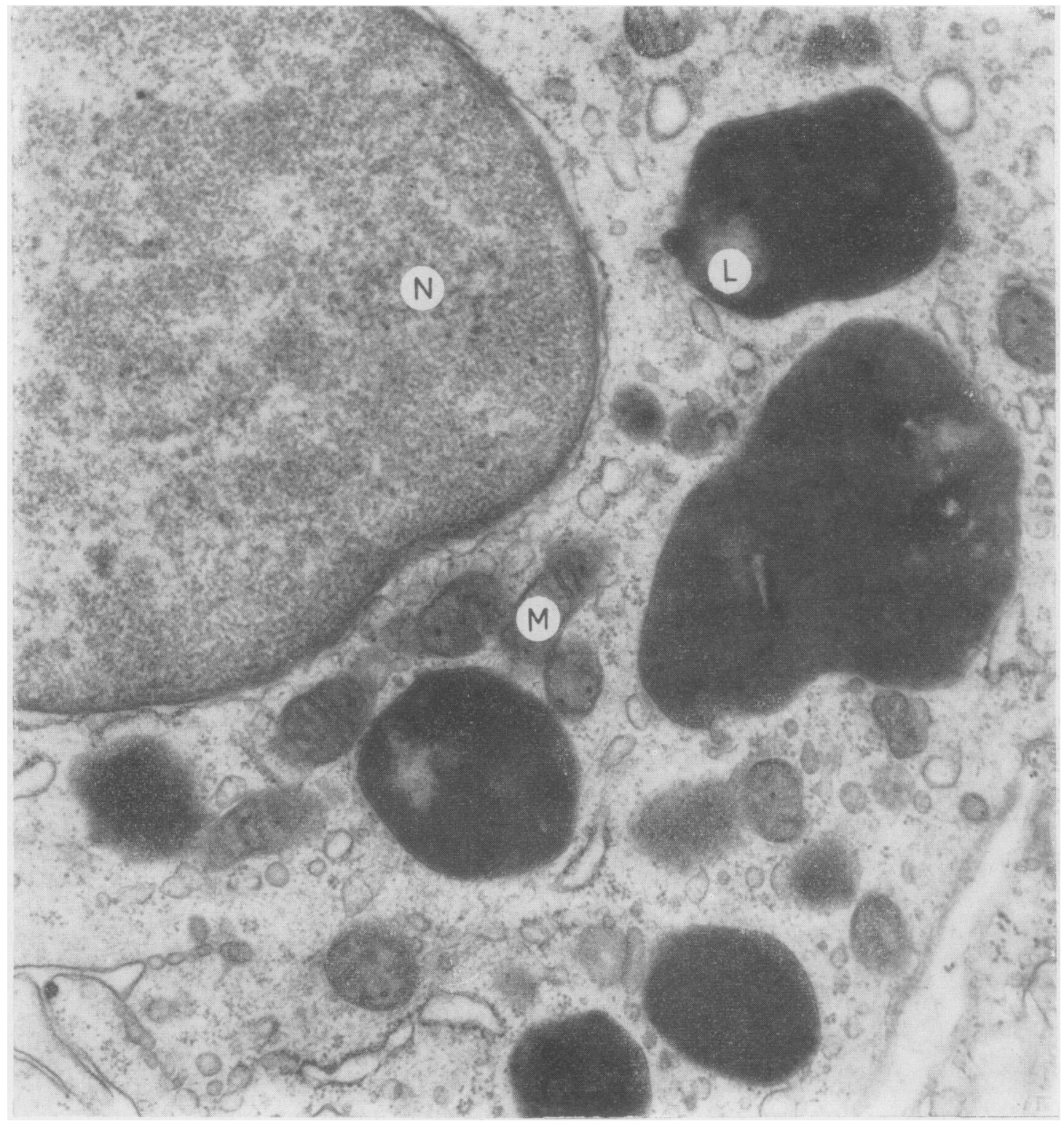

FIG. 13. Macrophage with nucleus $(N)$ and mitochondria $(M)$ containing lysosomes with a lipid component (L). Lead stain $\times 33,850$. 
PATHOGENESIS Search for a specific agent has so far proved fruitless. The features of a virus infection are not usually seen histologically nor from a study of our electron micrographs. Culture of the specimen for virus has been negative. Epidemiological and biochemical studies have yielded little help. Damage to the lung at the alveolar level may follow the inhalation of many noxious agents
(Gaensler, 1966) so that critical scrutiny of the patient's occupational history is essential. So far there seems little support for the view that this might be a new form of industrial lung disease, but it seems wise to keep an open mind by virtue of the many new industrial processes during which harmful gases or particulate matter are evolved. Whereas in the first of our two patients exposure

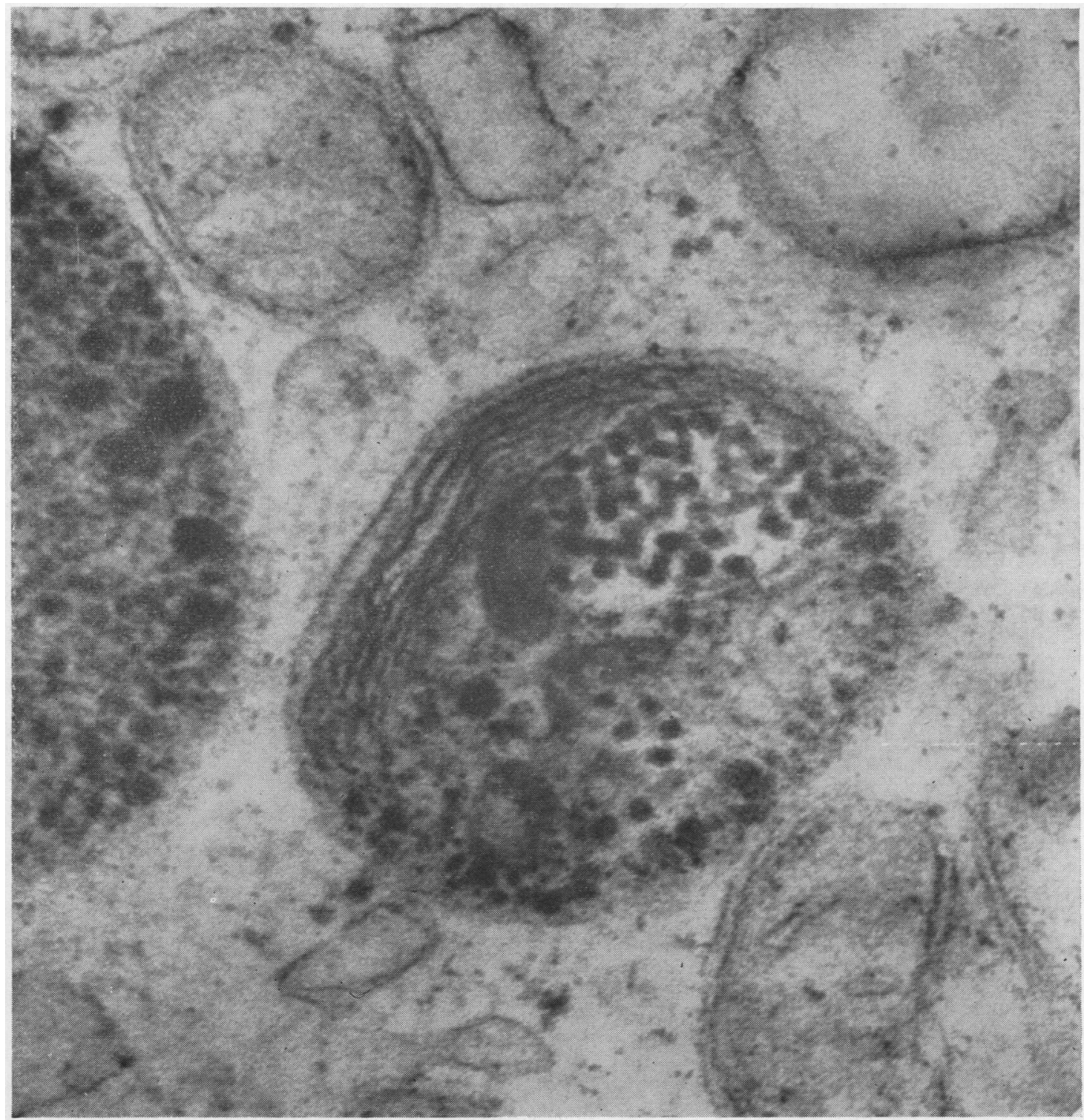

FIG. 14. Lysosomes of a macrophage showing dense granules, probably lipofuscin, and a peripheral array of lipoprotein membranes. Lead stain $\times 161,000$. 
to high pressure oxygen and to smoke and other air pollutants in the course of fire-fighting seem unlikely causes, there must be some doubt as to the influence of hair lacquers in case 2 . The differential diagnosis prior to lung biopsy included socalled 'thesaurosis due to hair-sprays' as well as idiopathic haemosiderosis and alveolar proteinosis. The histological picture of D.I.P. does not re- semble that described by Bergmann, Flance, and $\overrightarrow{\bar{s}}$ Blumenthal (1958) in their survey of thesaurosis, although Liebow (1968) states that some speci-o mens from hair lacquer lungs sent for examina $-\frac{\bar{m}}{5}$ tion did show a few of the features of D.I.P.

ELECTRON MICROSCOPY In D.I.P. the desquamated" cells and those lining the alveoli have all the

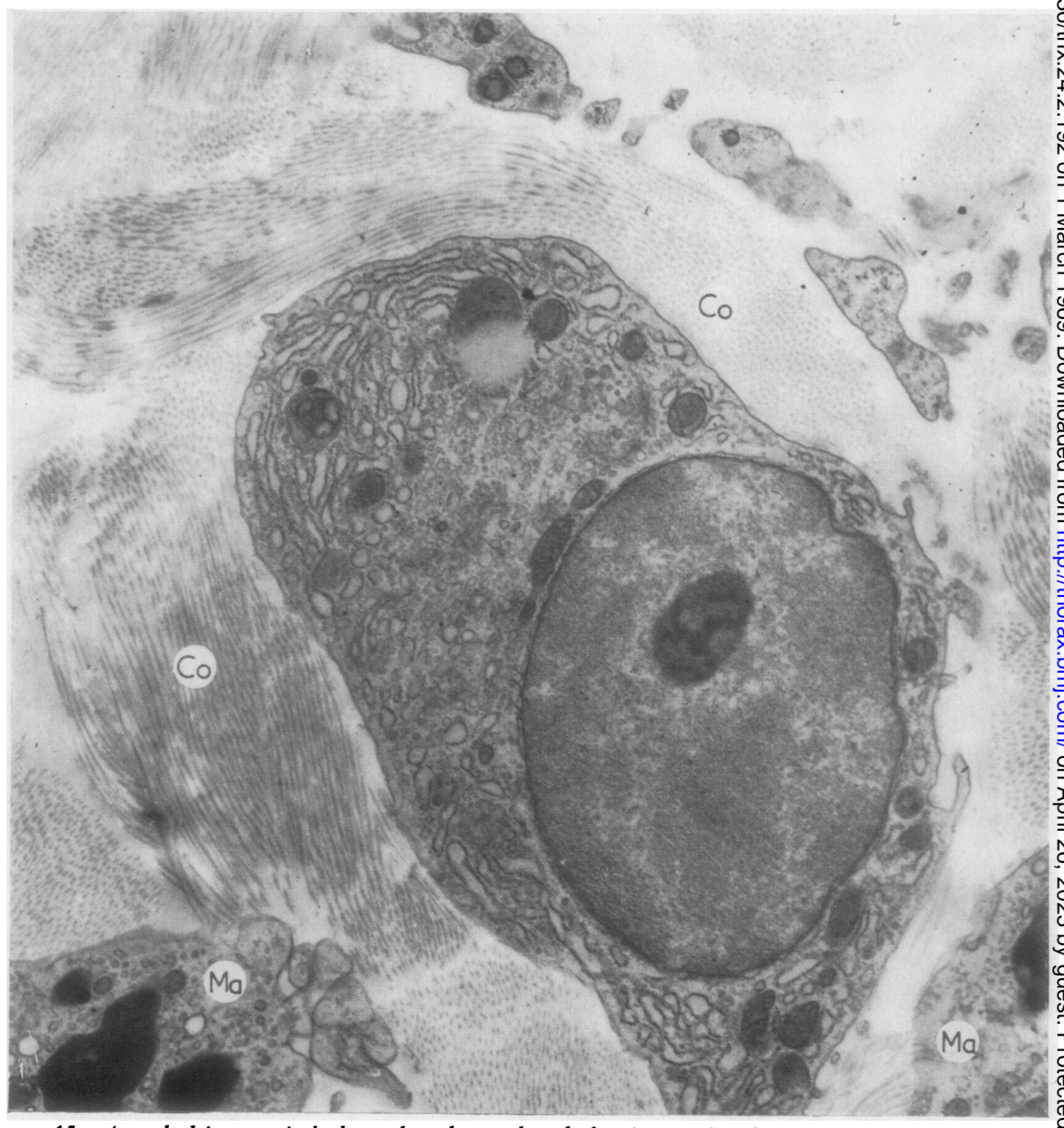

FIG. 15. A marked increase in both rough and smooth endoplasmic reticulum has occurred in this septal cell. Dense bands of collagen $(\mathrm{Co})$ surround it and two adjacent macrophages $(\mathrm{Ma})$. Lead stain $\times 12,700$. 
characteristics of the type 2 pneumonocyte described by Karrer (1956). The laminated inclusions, first described by Low (1954) and Schlipköter (1954), correspond to the P.A.S.-positive diastase-resistant granules, and impart the brownish colour prominent in haematoxylin and eosin stained sections. The laminated bodies in type 2 pneumonocytes are considered to be lysosomal in nature, since they show a positive acidphosphatase reaction (Buckingham, McNary, and Sommers, 1964 ; Hatasa and Nakamura, 1965) and are bounded by a unit membrane (Novikoff, Beaufay, and De Duve, 1956; De Duve, 1959). They have been linked with the surfactant property of the lung (Buckingham and Avery, 1962; Woodside and Dalton, 1958; Orzalesi, Motoyama, Jacobson, Kikkawa, Reynolds, and Cook, 1965) and electron microscopic evidence of their extrusion into the alveolar space has been shown (Leeson and Leeson, 1964, 1966; Hatasa and Nakamura, 1965 ; Kikkawa, Motoyama, and Cook, 1965). In D.I.P. we have not been able to observe secretion of the bodies. The two morphological forms that we describe, however, probably signify a process of ageing within the inclusion. A diligent search of the nuclei and cytoplasm of the desquamated and lining cells failed to show evidence of virus infection.

Macrophages among the desquamated cells and within septa showed a coarse granularity when stained with Mallory's stain for lipofuscin, correlating the dense granular component of the macrophage lysosome with lipofuscin. The intimate relationship of the lysosomes to the Golgi apparatus seen in Fig. 13 gives some insight into the origin of lysosomes described by Moe, Rostgaard, and Behnke (1965). Ferritin granules scattered throughout the cytoplasm of the macrophage, and present within their lysosomes in small quantities, correlate with the few faintly positive cells seen by the light microscope when Perl's stain for iron is used. The collagenous thickening of the septa is visual evidence of the diffusional impediment known to exist in these patients. Our ultrastructural findings amplify the brief mention made by Liebow et al. (1965) and recent reports by Goff, McNary, and Gaensler (1967), Heath (1968), and Brewer (1968) concerning the electron microscopic picture in this condition. The latter found a higher proportion of intra-alveolar macrophages, along with desquamated granular pneumonocytes, than were present in our case 2. This difference in the cell population may reflect phases in the tissue response as the disease develops or is modified by treatment.
RADIOGRAPHY We would contest the opinion that there is a unique radiographic picture. Indeed micro-nodular densities, as seen in case 2 , or even normal radiographic findings may be almost as common as the triangular haziness spreading from the hilar regions to the lung bases which received special emphasis in the original article by Liebow et al. (1965). Progressive shrinkage of the more involved parts of the lung is inevitable in the absence of treatment, but this radiographic picture is not exclusive and can be simulated by the appearance in scleroderma and other disorders.

RESPIRATORY PHYSIOLOGY Much will depend upon the stage and extent of the disease. At the time of clinical distress, hyperventilation on exercise, a dramatic fall in arterial oxygen tension and saturation on relatively mild effort, and a severe reduction in the transfer factor are characteristic features and easy to record. The absence of evidence of airway obstruction is noteworthy. None of these tests nor any other more sophisticated measurement is specific for D.I.P. They provide a mathematical yardstick whereby spontaneous improvement or response to therapy may be assessed objectively. In both our patients serial observations showed improvement in all the parameters that were measured. In case 2 it might be justifiable to consider her present respiratory physiology as within her normal range.

THERAPY Undoubtedly the most outstanding clinical feature of D.I.P. is its prompt response to corticosteroids. Spontaneous resolution has been described but it is not justifiable to await this event. Adequate therapy with prednisolone or similar compounds may be expected to transform the situation within a matter of days. Progressive disappearance of symptoms, increase in ability for exercise, clearing of radiographic shadows, and improvement in respiratory function characterize the clinical course of most patients. Unfortunately, serious relapse (as in case 2) may follow early withdrawal of the drug so that treatment may need to be continued for many months or years. When one considers the appearances under light and electron microscopy of case 2 , complete resolution and cure would seem impossible. The collagen lying within the alveolar walls and framework of the lungs could hardly be absorbed. This observation does not preclude an excellent subjective response and a return to 'normal' of all the disturbances that characterize the condition.

We wish to thank Dr. A. W. D. Leishman and Dr. A. M. Forrest for permission to publish details of cases 1 and 2 respectively, and Mr. A. G. Norman 
for performing the lung biopsy. Our thanks are also due to Miss E. Picton and Miss E. Milne for help in the assessment of respiratory function, and to Miss H. Sercome and Mrs. A. M. Robinson for secretarial assistance.

\section{REFERENCES}

Bergmann, M., Flance, I. J., and Blumenthal, H. T. (1958). Thesaurosis following inhalation of hair spray. A clinical and experimental study. New Engl.J. Med., 258, 471.

Brewer, D. (1968). Desquamative interstitial pneumonia (abstract). Thorax, 23, 330 .

Buckingham, S., and Avery, M. E. (1962). Time of appearance of lung surfactant in the foetal mouse. Nature (Lond.), 193, 688 .

- McNary, W. F., and Sommers, S. C. (1964). Pulmonary alveolar cell inclusions: their development in the rat. Science, 145, 1192.

De Duve, C. (1959). The function of intracellular hydrolases. Exp. Cell Res. Suppl., 7, 169.

Gaensler, E. A. (1966). Diagnostic techniques in diffuse or miliary lung diseases. Experience with 381 patients: Advances in Cardiopulmonary Disease, Vol. III, p. 81. Ed. Banyai, A. L., and Gordon, pulmonary Book Medical Publishers, Chicago.
B.L. Year Bo

Gaensler, E. A., Goff, A. M., and Prowse, C. M. (1966). Desquamative interstitial pneumonia. New Engl.J. Med., 274, 113.

Glauert, Audrey M. (1961). In Techniques for Electron Microscopy. Ed. Kay, D., pp. 179-181. Blackwell, Oxford.

Goff, A. M., McNary, W. F. Jr., and Gaensler, E. A. (1967). Desquamative interstitial pneumonia. Med. thorac. (Basel), 24, 317.

Hamman, L., and Rich, A. R. (1935). Fulminating diffuse interstitial fibrosis of the lungs. Trans. Amer. clin. climat. Ass., 51, 154. (1944). Acute diffuse interstitial fibrosis of the lungs. Bull.

Hatasa, K., and Nakamura, T. (1965). Electron microscopic observations of lung alveolar epithelial cells of normal young mice, with special reference to formation and secretion of osmiophilic lamellar bodies. $Z$. Zellforsch., 68, 266.

Heath, D. (1968). Desquamative interstitial pneumonia (abstract). Thorax, 23, 330 .
Karrer, H. E. (1956). The ultrastructure of mouse lung. Genera $\vec{F}$ architecture of capillary and alveolar walls. J. biophys. biochem? Cytol., 2, 241.

Kikkawa, Y., Motoyama, E. K., and Cook, C. D. (1965). The ultra structure of the lungs of lambs. The relation of osmiophilic inclusions and alveolar lining layer to fetal maturation ands experimentally produced respiratory distress. Amer. J. Path., $47 \overrightarrow{7}$ 877.

Leeson, T. S., and Leeson, C. R. (1964). A light and electron micro scope study of developing respiratory tissue in the rat. J. Anat (Lond.), 98, 183 . - (1966). Osmiophilic lamellated bodies and associated $\vec{b}$ material in lung alveolar spaces. $J$. Cell Biol., 28, 577 .

Liebow, A. A. (1968). Personal communication. Steer, A., and Billingsley, J. G. (1965). Desquamative inter $\omega$ stitial pneumonia. Amer. J. Med., 39, 369.

Low, F. N. (1954). The electron microscopy of sectioned lung tissue after varied duration of fixation in buffered osmium tetroxide
Anat. Rec., 120, 827.

Moe, H., Rostgaard, J., and Behnke, O. (1965). On the morphology and origin of virgin lysosomes in the intestinal epithelium of the rat. J. Ultrastruct. Res., 12, 396.

Novikoff, A. B., Beaufay, H., and De Duve, C. (1956). Electror microscopy of lysosome-rich fractions from rat liver. $J$. Biophys Biochem. Cytol., 2, Suppl. (Conference on Tissue Fine Structure) p. 179.

Orzalesi, M. M. Motoyama, E. K., Jacobson, H. N., Kikkawa, Y. Reynolds, E. O. R., and Cook, C. D. (1965). The development
of the lungs of lambs. Pediatrics, 35, 373.

Palade, G. E. (1952). A study of fixation for electron microscopy $\frac{\overline{\widehat{T}}}{\widehat{T}}$ J. exp. Med., 95, 285 .

Persaud, V., Bateson, E. M., Ling, J. A., and Hayes, J. A. (1967) $\overrightarrow{0}$ Desquamative interstitial pneumonia. Brit. J. Dis. Chest, 61, 159 o

Reynolds, E. S. (1963). The use of lead citrate at high $\mathrm{pH}$ as an electron-opaque stain in electron microscopy. J. Cell Biol., 17 208.

Scadding, J. G. (1964). Fibrosing alveolitis. Brit. med. J., 2, 686.

and Hinson, K. F. W. (1967). Diffuse fibrosing alveolitis (diffuse interstitial fibrosis of the lungs). Correlation of histology a biopsy with prognosis. Thorax, 22, 291 .

Schlipköter, H. W. (1954). Elektronenoptische Untersuchungen ultadünner Lungenschnitte. Dtsch. med. Wschr., 79, 1658.

Woodside, G. L., and Dalton, A. J. (1958). The ultrastructure of lungtissue from newborn and embryo mice. J. Ultrastruct. Res., $2,28$. 